This is a post-print (i.e. final draft post-refereeing) of a manuscript published in the Journal of Management \& Organization.

To cite this article: Cândido, C.J.F. and S.P. Santos (2015) Strategy implementation: What is the failure rate? Journal of Management \& Organization,21(2),237-262. DOI: http://dx.doi.org/10.1017/jmo.2014.77

To link to this article: http://journals.cambridge.org/abstract_S1833367214000777

Copyright: (c)2015 CambridgeUniversity Press andAustralian andNewZealandAcademy of Management

\title{
Strategy implementation: What is the failure rate?
}

\author{
Carlos J. F. Cândido *
}

CEFAGE-UAlg, Faro, Portugal

Faculty of Economics, University of Algarve

Campus de Gambelas, Edificio 9, 8005-139 Faro, Portugal

E-mail: ccandido@ualg.pt

Tel.: + 351289800915 Fax.: + 351289800 063/4/5

\section{Sérgio P. Santos}

CEFAGE-UAlg, Faro, Portugal

Faculty of Economics, University of Algarve

Campus de Gambelas, Edificio 9, 8005-139 Faro, Portugal

E-mail:ssantos@ualg.pt

Tel.: + 351289800915 Fax.: + 351289800 063/4/5

\section{Acknowledgement}

The authors thank two anonymous referees for the insightful comments and helpful suggestions. The authors are also pleased to acknowledge the financial support from Fundação para a Ciência e a Tecnologia (SFRH/BSAB/863/2008), FEDER/COMPETE (grant PEst-C/EGE/UI4007/2011), Faculdade de Economia, Universidade do Algarve, and Newport Business School, University of Wales.

\footnotetext{
* Corresponding author
} 


\title{
Strategy implementation: What is the failure rate?
}

\begin{abstract}
It is often claimed that 50 to 90 percent of strategic initiatives fail. Although these claims have had a significant impact on management theory and practice, they are controversial. We aim to clarify why this is the case. Towards this end, an extensive review of the literature is presented, assessed, compared and discussed. We conclude that whilst it is widely acknowledged that the implementation of a new strategy can be a difficult task, the true rate of implementation failure remains to be determined. Most of the estimates presented in the literature are based on evidence that is outdated, fragmentary, fragile, or just absent. Careful consideration is advised before using current estimates to justify changes in the theory and practice. A set of guiding principles is presented for assisting researchers to produce better estimates of the rates of failure.
\end{abstract}

Keywords: strategy implementation, business strategy, corporate strategy, strategic change management, failure rate, success.

JEL Classification: M10, D04. 


\section{Introduction}

The Business Policy field was founded at the start of the twentieth century (Rumelt et al., 1994; Hambrick and Chen, 2008) and strategic management was formally born in the 1960s (Amitabh, 2010), when Chandler (1962), Ansoff (1965) and Learned et al. (1965) published their pioneering books. Since then, strategic management has gone through several stages (Ansoff et al., 1976, O’Shannassy, 2001), taken many forms (Mintzberg et al., 1998) and changed profoundly. One of the most challenging and unresolved problems in this area is the 'apparently high' percentage of organisational strategies that fail, with some authors estimating a rate of failure between 50 and 90 percent (e.g. Kiechel, 1982, 1984; Gray, 1986; Nutt, 1999; Kaplan and Norton, 2001; Sirkin et al., 2005). By failure we mean either a new strategy was formulated but not implemented, or it was implemented but with poor results. This is a simple definition but still consistent with the three features of a successful implementation as defined by Miller (1997): (1) completion of everything intended to be implemented within the expected time period; (2) achievement of the performance intended; and (3) acceptability of the method of implementation and outcomes within the organisation. It is also consistent with the planned and emergent strategy modes. In both strategy modes, strategy may or may not be completed, may achieve different degrees of performance and its acceptability may also vary.

The difficulty of successfully implementing new business strategies has long been recognised in the literature (e.g. Alexander, 1985; Wernham, 1985; Ansoff and McDonnell, 1990), and a 1989 Booz Allen study (cited by Zairi, 1995) concluded that most managers believe that the difficulty of implementing strategy surpasses that of formulating it. As an example, the study found that $73 \%$ of managers believed that implementation is more difficult than formulation; $72 \%$ that it takes more time; and $82 \%$ that it is the part of the strategic planning process over which managers have least control. 
In order to understand the reasons behind failure and improve the success rate of implementation, several researchers have provided comprehensive sets of implementation difficulties (Alexander, 1985; Wernham, 1985; Ansoff and McDonnell, 1990; O’Toole, 1995; Beer and Eisenstat, 2000; Cândido and Morris, 2000; Hafsi, 2001; Miller et al., 2004; Sirkin et al., 2005; Hrebiniak, 2006; Cândido and Santos, 2011; and Gandolfi and Hansson, 2010, 2011). Many researchers - some of which following on from the inspiring work of Lewin (1947) - have also proposed integrated frameworks for strategy formulation and successful implementation (e.g. Ansoff and McDonnell, 1990; Gioia and Chittipeddi, 1991; BadenFuller and Stopford, 1994; Kotter, 1995; Hussey, 1996; Galpin, 1997; Johnson and Scholes, 1999; Calori et al., 2000; Cândido and Morris, 2001). Some others have adopted a different approach and decided to empirically test the impact of these frameworks and of their success factors (e.g. Pinto and Prescott, 1990; Miller, 1997; Bauer et al., 2005; Bockmühl et al., 2011).

Several major debates in the literature (Eisenhardt and Zbaracki, 1992) have also contributed to the advancement of possible solutions to the implementation problem, namely those around the rationality of the strategy formation process (Fredrickson and Mitchell, 1984; Fredrickson and Iaquinto, 1989; Dean and Sharfman, 1993; Papadakis et al., 1998); the accidental, evolutionary or natural selection approaches of strategy (Alchian, 1950; Cohen et al., 1972; Nelson and Winter, 1974; Hannan and Freeman, 1977; Aldrich, 1979; March, 1981; Van de Ven and Poole, 1995); the rate, rhythm or pattern of organisational change (Dunphy and Stace, 1988; Weick and Quinn; 1999); the incremental or emergent additions to intended strategy (Mintzberg and Waters, 1985; Mintzberg, 1987; Quinn, 1989); the idiosyncratic nature of each individual strategic decision (Mintzberg et al., 1976; French et al., 2011); the impact of top management team composition and relationships between members (Hambrick and Mason, 1984; Naranjo-Gil et al., 2008; O’Shannassy, 2010); the alternative management 
styles and strategic change methods (Hart, 1992; Stace and Dunphy, 1996; Johnson and Scholes, 1999; Balogun and Hailey, 2008); the distinction and relationships between strategy process, content and context (Pettigrew, 1987; Barnett and Carroll, 1995); and also the 'less rational': political, cultural, behavioral, learned and even symbolic aspects of effective strategic change (Cyert and March, 1964; Carnall, 1986; DeGeus, 1988; Senge, 1990; Gioia and Chittipeddi, 1991; March, 1997; Nonaka, 2007; Goss, 2008).

Although remarkable progress has been made in the strategic management field, the problem of strategy implementation failure persists, and it is still an important and ongoing concern for researchers and practitioners (Mockler, 1995; Barney, 2001; Hickson et al., 2003)

Probably, one of the most important challenges in this area is to discover how to ensure successful implementation. A useful first step in this direction is to assess what the real scale of the problem is. This assessment is important for three main reasons. One important reason is that currently both researchers and practitioners seem to assume that the rates of failure are very high. Considering that some of the high estimates have been used to guide some of the research and practice on strategic management, an assessment of the extent to which they provide an accurate and up-to-date account of the problem of strategy implementation failure is required. This is particularly relevant as some of the estimates presented in the literature have played an important role on the adoption or abandonment of some management tools by practitioners, and on the choice of topics researched by academics. Therefore, a rigorous assessment of the extent of the problem can assist decision makers to make better informed decisions on strategies to adopt and on topics to research.

A second reason in favour of this assessment is that it will allow to determine whether the failure rates estimated over the years show any particular pattern or trend. This can be an important finding as it might indicate important changes in the way strategies have been 
implemented over the years, changes in the nature of the strategies, or changes in the way implementation success has been measured. Therefore, identification of clear patterns or trends in the results can open several avenues for research. In particular, it can be an important catalyst for research on the reasons behind the patterns observed.

The other main reason is that the percentage of strategies that fail to succeed is a controversial issue as no one seems to know what the real rate of failure is. By reviewing and discussing relevant literature, this research provides a clear and comprehensive understanding of the nature of this problem, so that the factors contributing to it can be identified and properly addressed. In doing so, this research exposes the need for, and lays the foundations of a clear protocol to guide researchers in the process of estimating more rigorously the rates of failure on strategy implementation. The development of this protocol is fundamental to assist managers and researchers in making better judgments of the value of strategy types, implementation approaches and management instruments.

This paper therefore aims to contribute to the discussion on the estimation of strategy implementation failure rates. In particular, we aim to show that the current state of affairs on the field of strategic management does not allow a single robust estimate of the failure rate of strategy implementation to be provided. In line with this objective, we also aim to suggest a template for a protocol that can help researchers develop better measures of strategy implementation failure rates. To this purpose, an extensive review of the literature on strategy implementation failure rates is presented and scrutinised.

In pursuit of this research agenda, the remainder of this paper is organised into several sections. It starts by discussing the research methodology and the process we have followed to address the objectives of this paper. It then addresses the issue of what the rate of strategy implementation failure is. A discussion of the literature dealing with this issue ensues and evidence is presented that supports the conclusions we have reached. The paper concludes by 
deriving implications for the literature and practice on strategy implementation.

\section{Methodology: Search strategy and selection criteria}

With the objective of assessing what the rate of business strategy implementation failure/success is, we carried out an extensive review of the literature. First we tried to identify all publications in scholarly journals at the EBSCO Host Research Databases that present estimates for this rate. Several search strings, including strateg* and fail*, strateg* and success*, strateg* and implement*, transfor* and fail* were applied to keywords, titles, and abstracts of the publications. In the search strings above, the asterisk sign $(*)$ represents wildcard characters. Second, within this first set, we identified all papers from business journals. All those publications from the list that were not actually publications in the business area even though they mentioned the search terms in the keywords, title or the abstract were omitted from further analysis. Third, we analysed the abstracts of all publications on this final list in order to assess their relevance for our research. We have considered only relevant studies that could present a percentage of failure (or of success) on business strategy execution consistent with the definition of failure presented previously. Fourth, for those publications considered to be relevant, we analysed the full text in order to determine whether an estimate of the failure rate was provided. Fifth, bibliographic references in the selected papers were also used as a source to identify papers or other evidence not captured in our electronic database search. It is relevant to note that the studies dealing with this issue have been authored by academics and practitioners, including consulting companies, and that not all of these studies have been published in academic journals. Therefore, a search strategy based exclusively on evidence documented in academic journals would be incomplete. Consequently, our sixth step consisted of additional searches carried out on the Internet search engine Google, on the web-sites of major consulting companies, and on several national library on-line catalogues (England, U.S.A., Ireland, Scotland, Canada, 
Australia, and Portugal) which allowed the identification of some additional and relevant studies. Unfortunately, however, some of these studies were not available for consultation and it was not possible for us to gain access to either a hard or an electronic copy. Interestingly, many of these unavailable studies were authored by consulting companies (A.T. Kearney, 1992; Arthur D. Little, 1992; and Prospectus, 1996) and were abundantly quoted, even by reputed academic researchers. Finally, we have also contacted by e-mail the consulting companies, the individual authors of the reports, when their names were publicly available, and the authors who have quoted those studies. In total, more than 45 e-mails were sent. In spite of all the efforts made to obtain copies of the studies, most of these efforts proved unfruitful. Many of the companies and authors contacted replied, but we did not succeed in obtaining the required information either because the studies were no longer available (e.g. A.T. Kearney, A.D.L., Prospectus) or because the companies were unable to assist individuals with specific research requests (e.g. B.C.G., McKinsey).

Therefore, the literature reviewed in this paper includes all the academic studies that have met the search criteria above and the consultancy studies that were relevant and available for consultation. The latter account for $45 \%$ of the studies analysed. The results of this search are presented and discussed in the next section.

\section{Strategy implementation failure/success rates}

Although the literature on the topic of strategy implementation failure/success is not in short supply, the existing studies are mixed in terms of their features (e.g. failure rate estimated, amount of effort involved in the estimation, complexity and quality of the methodology used, unit of analysis, criteria adopted to define success, and research strategies adopted) and this requires special care in comparing their results. The most significant features of the studies considered for this research are summarised in tables 1 and 2. Table 1 lists studies which have focused on general business strategies, and Table 2 studies which have focused on specific 
business strategies. Although the former table aims to be exhaustive, in the sense that it shows all the studies that our search strategy identified, the latter, aims to be illustrative of the variability of the available estimates.

The information in these tables is organised in five columns. The first column indicates the author(s) and year of the study and it is listed chronologically. The research method used to estimate the rates of failure/success and the variables against which such rates were assessed are described in the second and third columns, respectively. The fourth column indicates the estimated rate of failure presented by each study. Finally, the last column records some additional comments on each study.

PLEASE, INSERT TABLES 1 AND 2 HERE

The most appropriate conclusion that can be drawn from the analysis of tables 1 and 2 is that it is difficult to provide accurate estimates for rates of failure of strategy implementation. The studies carried out so far by researchers and management consulting firms have obtained mixed results regarding the success and failure rates of business strategy implementation. In fact, as can be seen from the fourth column of the tables, the range of variation of the estimates is remarkable. If we first analyse the studies that focus on business strategy implementation in general, we can verify that the estimated rates of failure have ranged from 28 to 90 percent. When we turn to the studies that have focused on the implementation of specific business strategies this range is even wider. Whilst some studies have obtained rates of failure as low as 7 to 10 percent (e.g. Taylor, 1997; Walsh et al., 2002), others have obtained rates of failure as high as 80 to 90 percent (e.g. Voss, 1988, 1992; A. T. Kearney, 1992). Therefore, although it can be claimed that up to 90 percent of strategic initiatives fail, as this is the upper limit of the estimates provided in the literature, this is likely to be an overestimation. 
Two major reasons support this view. Firstly, most of the higher estimates presented in the literature come from consulting firms (e.g. Kiechel, 1982, 1984; Judson, 1991; A.T. Kearney, 1992; Prospectus, 1996; Hackett Group, 2004a, 2004b; Dion et al., 2007). Although we were unable to access the scientific rigour of some of these studies, as it was not possible to obtain details regarding the robustness of the research methodologies used and the results achieved, it has long been recognised that some overestimation may have been committed by consulting firms (Powell, 1995). Overestimated failure rates can be used to the advantage of consulting firms, namely as a marketing strategy to convince customers of the importance of adopting their services (Powell, 1995). Secondly, the results on the tables seem to suggest a downward trend on the estimates of failure, indicating that the percentage of strategic initiatives that fail has decreased over time (see Figure 1), a likely result of the scientific progress made in this field over the past two decades and its inclusion in business education programmes. In particular, the identification of obstacles to strategy implementation and a better understanding of the ways they interact with each other, made by both researchers and practitioners (e.g. Alexander, 1985; Ansoff and McDonnell, 1990; Kotter, 1995; Beer and Eisenstat, 2000; Kaplan and Norton, 2001) might have played an important role in improving the rates of failure over the years. Therefore, although some of the higher estimates could have been appropriate and reflect the true dimension of the problem one or two decades ago, they are likely to be outdated nowadays. This is also the case because time since adoption of a new strategy contributes to a better internalization of the elements of that strategy and consequently to a better performance (Powell, 1995; Prajogo and Brown, 2006). Considering that some strategies and some management tools have been in practice for a long time, it is likely that familiarity with these strategies and tools has increased leading to the accumulation of knowledge and, consequently, to more successful implementations (Taylor and Wright, 2003). Several other explanations can be offered to justify the downward trend on the 
estimates of failure. For example, companies may follow successful early adopters, benefiting from their experience, thus resulting in the improvement of failure rates. Companies may also have become more aware of the need to carefully customise new strategies or management tools to their characteristics and to the contexts in which they operate, instead of blindly adopting general undifferentiated strategies and tools. Independently or in combination each of these factors might help explain the apparent improvement in failure rates.

\section{PLEASE, INSERT FIGURE 1 HERE}

It seems therefore reasonable to assume that the current rates of failure are well below some of the estimates often quoted in the literature. However, if this is the case, what is then the real percentage of strategies that fail? Although there have been several studies on this issue in the past two decades, our view is that the current state of affairs does not allow a robust estimate to be provided. Several reasons can be advanced for this.

Firstly, the studies discussing the success/failure rate of strategy implementation vary considerably in the amount of effort put into the estimation of the rate. In some of these studies the estimation of the rate of failure/success was their main objective (e.g. Golembiewski, 1990; Park, 1991; Wilkinson et al., 1994; Pautler, 2003; Makino et al., 2007). In other studies, this objective was part of a broader research agenda (e.g. Beamish, 1985; Voss, 1988, 1992; Taylor, 1997; Nutt, 1999; Walsh et al., 2002; Taylor and Wright, 2003; McKinsey, 2006), while in others the rates of success/failure were presented as complementary information in an introduction or as an aside (e.g. Gray, 1986; Harrigan, 1988a; Hall et al., 1993; Mohrman et al., 1995; Lewy and Mée, 1998a, 1998b; Sila, 2007). An implication of the effort put into the estimation of the rate in each study is the consequent impact on the complexity of the computational method used. In some studies, the computation is very simple (e.g. Beamish, 1985; Harrigan, 1988a; Sila, 2007), while in others it is much 
more complex and demanding (e.g. Golembiewski, 1990; Park, 1991).

Secondly, these studies are not easily comparable because the criteria used to define success/failure are very distinct and consequently, they can account for some of the differences between estimations. It is possible to distinguish between 'technical success' and 'competitive success' (Voss, 1992), between 'success as process ease' and 'success as process outcomes' (Bauer et al., 2005) and, similarly, between 'implementation success' and 'organisational success' (Hussey, 1996; Mellahi and Wilkinson, 2004). The higher rates of failure estimated may depend on a stricter sense of success adopted by researchers.

Estimates of technical success and success as process ease may be higher than estimates of success as process outcomes or organisational competitive success in the marketplace, since more internal and external contingencies can affect the latter types of success. In tables 1 and 2 we have reported mainly failure rates from a 'competitive success' or an 'organisational success' perspective. Even so, the studies in the tables are not easily comparable because in some cases researchers relied on managements' perceptions to derive an estimate of success/failure (e.g. Beamish, 1985; Gray, 1986; Voss, 1988, 1992; Taylor and Wright, 2003), whereas in others, they used more objective measurements (e.g. Golembiewski et al., 1981, 1982; Golembiewski, 1990; Hall et al., 1993; Pautler, 2003; Makino et al., 2007). Furthermore, some studies have used a single criterion to define success/failure (e.g. Gray, 1986; Walsh et al., 2002; Sila, 2007) whereas others have used multiple criteria (e.g. Golembiewski, 1990; Park, 1991; Wilkinson et al., 1994; Mohrman et al., 1995).

Thirdly, different studies have used different research strategies to estimate the rate of success/failure of strategy implementation. Some researchers have adopted a case study approach (e.g. Voss, 1988, 1992; Hall et al., 1993; Lewy and Mée, 1998a, 1998b; Nutt, 1999). Others have employed a survey method (e.g. Beamish, 1985; Wilkinson et al., 1994; Mohrman et al., 1995; Walsh et al., 2002; McKinsey, 2006; Makino et al., 2007; Sila, 2007), 
while still others have used a combination of methods (e.g. Gray, 1986; Harrigan, 1988a; Charan and Colvin, 1999; Taylor and Wright, 2003). It is well know that, whilst some research strategies allow statistical generalisations to be made, others, like case based research, only allow analytical generalisations.

Fourthly, the unit of analysis varies considerably from one study to another. Some researchers have considered as their unit of analysis a single project, such as developing a new product or launching quality circles, which may be seen as part of wider strategic initiatives (e.g. Nutt, 1987, 1999; Voss, 1988, 1992; Park, 1991; Lewy and Mée, 1998a, 1998b; Hackett Group, 2004a, 2004b; Lawson et al., 2006, 2008). Other researchers have focused on business wide strategic initiatives, which may in turn be decomposed into several smaller projects (e.g. Kiechel, 1982, 1984; Harrigan, 1988a, 1988b, 1988c; Mohrman et al., 1995; Walsh et al., 2002; Pautler, 2003; McKinsey, 2006; Sila, 2007).

Fifthly, some studies prove very difficult to obtain/access, in particular those undertaken by some management consulting firms such as A. T. Kearney, Arthur D. Little, McKinsey, Prospectus and Booz Allen Hamilton. Therefore, any conclusions taken from the estimates they have produced without a proper understanding of the context, methodology and results obtained might lack legitimacy and scientific rigour. In spite of this, it is common to find researchers (e.g. Holder and Walker, 1993; Mintzberg, 1994: 25, 284; Smith et al., 1994; Zairi, 1995; Dow et al., 1999; Korukonda et al., 1999; Kaplan and Norton, 2001: 1; Walsh et al., 2002; Sterling, 2003) that quote the results of these studies not because they have read the original work but because these estimates have been quoted by other researchers or in well known journals such as 'The Economist' or 'The Wall Street Journal'. Unfortunately, this has lead some of these studies to be widely misquoted and misunderstood (Taylor, 1997).

Finally, it is not always easy to distinguish what is fact and what is fiction in some of the estimates offered in the literature. In particular, there seems to be no scientific grounds behind 
some of the estimates. For example, Mintzberg (1994: 25, 284), Kaplan and Norton (2001: 1), Burnes (2004, 2005), Raps (2005) and Sila (2007) quote several sources for the rates of failure they mention in their papers (e.g. Kiechel, 1982, 1984; Judson, 1991; Dooyoung et al., 1998; Beer and Nohria, 2000; Waclawski, 2002; Sirkin et al., 2005). However, a detailed analysis of these sources shows that they did not carry out an estimation of the quoted rates of failure. They claim their estimates were based on 'Interviews', 'Studies', 'Experience', 'The Literature' or 'Popular Management Press', rather than on solid empirical evidence. On other occasions, the sources of the estimates are incorrectly interpreted (e.g. Kaplan and Norton, 2001, in interpreting the findings of Charan and Colvin, 1999). We also found evidence of studies incorrectly identifying their sources (e.g. Dyason and Kaye, 1997) and studies not identifying their sources at all (e.g. Jantz and Kendall, 1991; Neely and Bourne, 2000; Becer et al., 2007).

Unless these factors are accounted for, any attempts to present estimates for the real success/failure rates of strategy implementation are doomed to fail or are of little practical value.

Independently of the 'real' success/failure rate, and despite success rates that seem to have improved over time, it is reasonable to conclude that the number of strategic initiatives that fail is still considerably higher than would be desirable. This suggests that organisations either need better implementation guidelines or need to make better use of the existing ones. The need for better implementation processes has been widely acknowledged by researchers (e.g. Dean and Bowen, 1994; Mockler, 1995; Barney, 2001; Hickson et al., 2003) and research on how to avoid implementation obstacles and improve implementation has been underway for many years (e.g. Stanislao and Stanislao, 1983; Alexander, 1985; Ansoff and McDonnell, 1990; Kotter, 1995; Beer and Eisenstat, 2000; Miller et al., 2004; Stadler and Hinterhuber, 2005). It is, therefore, imperative to assess the extent to which these guidelines 
account for some of the improvements achieved as well as to understand the reasons why so many initiatives still fail.

Although efforts should be made to reduce failure rates, it is important to emphasise that failure can be seen as an important part of the strategic learning process within organisations (e.g. Mintzberg, 1987; Krogh and Vicari, 1993; Sitkin et al., 1994; Edmondson, 2011). Unintended past mistakes and deliberate strategic experiments can both generate useful lessons (Wilkinson and Mellahi, 2005) which may prove highly advantageous in the marketplace (Krogh and Vicari, 1993).

\section{Conclusion}

Business strategy implementation has long attracted the interest of researchers and practitioners. In spite of being often quoted that 50 to 90 percent of strategic initiatives fail (e.g. Mintzberg, 1994: 25, 284; Kaplan and Norton, 2001: 1), an exhaustive analysis of the literature on strategy formulation and implementation seems to suggest that some of the evidence supporting these figures is outdated, fragmentary, lacks scientific rigour or is just absent. Much of the uncertainty relating to this issue is also due to the fact that different studies have obtained mixed results. These findings are important to the field of strategy and change management in two different ways. Firstly, they add to the discussion of the appropriateness of the failure rates proposed by some studies, which has attracted interest in recent years but on which much remains to be done. As far as we know, there are only two studies which explicitly address this issue. A paper by Cândido and Santos (2011), which focuses on Total Quality Management rates of failure, and a paper by Hughes (2011), which questions the assertion that ' 70 per cent of all organisational change initiatives really fail'. Our research presents, however, important departures from these previous studies. Whilst the former study focused on the implementation of a specific business strategy (i.e. TQM) and the latter focused its analysis exclusively on five selected papers, none of which presenting 
evidence to support the claim they had made, our study is much broader in focus and comprehensive in the analysis. We scrutinise both the implementation of general and specific business strategies and carry out an extensive review of all the studies that discuss strategy implementation failure rates. In so doing, we have found out that the range of variation of the estimates is remarkable, spanning from a rate of failure as low as 7 to one as high as 90 percent. Several factors can help explain why there is such variation in the estimates produced including possible overestimation, exposure of organisations to different contextual and environmental factors and differences in the concepts used to define success/failure and in the samples and methodologies adopted. These differences can be attributed to several factors, one of the most important being the lack of a comprehensive review of the relevant literature by some of the studies. This has prevented the authors of these studies from becoming aware of the state of the art on the topic and, consequently, adopting concepts and methods consistent with previous research. Another important explanation for the differences mentioned above relates to the fact that the research objectives vary considerably between studies. Some studies have established the estimation of the rate of failure as their main goal, whereas in others, the estimation of this rate has assumed a less important role. This has had various implications for the higher or lower sophistication of the methodology and of the criteria adopted for the calculations. A third factor explaining the differences in the criteria and methods used to estimate failure rates relates to the use that is intended for these rates. Whist academic researchers are likely to be more interested in the study of a particular type of implementation approach/tactic, strategy, or even management instrument (such as balanced scorecard or TQM), practitioners are likely to be more interested in the promotion of a specific kind of consulting service. Finally, the fact that the literature does not offer a clear research protocol to be followed when the objective is to estimate the rate of failure in the implementation of strategic initiatives, also plays a fundamental role in explaining the 
differences between studies. Given the exceptionally broad range of estimates produced as a result of the factors mentioned above, their quotation in generic terms may have little more than academic value. This conclusion should also be seen as a warning against the use of the current higher estimates of rates of failure (70 to 90 percent) to justify any course of action, whether in research or in management practice.

Another important contribution of this research to the literature is that it exposes the need for and lays the foundations of a protocol that guides researchers in the process of estimating strategy implementation failure rates. This is a distinctive feature from the two studies previously discussed. In what follows we propose a template for such a protocol, which is aimed at enhancing the comparability between estimates and increasing their predictive capability. This protocol should be regarded, however, as a starting point for discussion rather than as a complete proposal. As discussed in what follows, when the objective is to estimate strategy implementation failure rates, there are 5 principal aspects of the protocol.

Firstly, it is important to accurately characterise the context of the study. In particular, it is fundamental that relevant organisational factors (e.g. firm size, sector of operation, ownership, management style) and environmental variables (e.g. economic, social, and cultural context) that might impact on the degree of success or failure of a strategy are clearly identified and discussed. It is well known that some contingency factors might impact on the success or failure of a strategic initiative, and therefore, knowing them is important to enhance comparability between estimates and to design tailor made guidelines for implementation.

Secondly, once the context has been established, the actual types of the business strategies being assessed must be carefully detailed. Considering that the process of implementing different strategies can have quite different outcomes within the same 
organisational and/or environmental context, it is critical to clarify which type of strategy is being analysed. Besides this, it is important to clarify whether the study is assessing the success/failure of modifications of existing strategies or the implementation of whole new strategies and whether it is focused on transactional or transformational changes.

Thirdly, it is fundamental to establish a clear and consistent definition of "failure" or of "success". Although a universally acceptable definition of strategy implementation failure is not compulsory, a clear definition is nonetheless important for methodological consistency as it will ensure a common understanding of what is being assessed and enhance comparability between studies. As part of this definition, it is fundamental to specify the intended outcomes of the implementation process, the measureable indicators of these outcomes and the specific target levels to be attained for these indicators in order for an implementation to qualify as a success (or as a failure).

Fourthly, the research methodology used to estimate the rate of failure has to be clearly discussed. Considering that a crucial aspect in estimating the degree of success/failure of strategy implementation is the ability to identify and quantify the outcomes of the process, and that different research strategies have often distinctly different methods for data collection and analysis, it is important that these methods and their assumptions are properly discussed. Information regarding the reliability and validity of the measurement instruments must also be provided to allow for an independent assessment of their methodological rigor and consistency.

Finally, as in any carefully done research, weaknesses of the analysis which may limit the ability to generalise its conclusions to other contexts, must be identified and characterised. The identification of these weaknesses and the provision of suggestions on how to address them is a key step towards improvement.

Adherence to this protocol is imperative for a better understanding of the reasons behind 
the different estimates produced and to derive more robust estimates for the rates of strategy implementation failure. Only in this way will we be able to identify the real scale of the problem and plan appropriate corrective actions. Unless it is properly understood whether there are strategic initiatives more difficult to implement than others, whether there are sectors or areas of activity where strategies are more difficult to implement, and whether there are cultural issues and other contextual factors that explain the differences on the estimates produced, the mere quotation of these estimates will be of little practical value.

It is important to acknowledge, however, that considerable progress has been made on this topic in the last two decades, and that the lower failure rates recently estimated by some researchers might be a consequence of these advances. However, while progress has been achieved there are still a number of issues that need further understanding to better guide research and practice on this issue.

Firstly, it is important to understand whether the rates of failure are context-dependent. The fact that the estimates produced are so different might suggest context-dependence, indicating that implementation should be tailored in accordance to the characteristics of the organisations and/or of their environment.

Secondly, it is important to understand whether the apparent improvement in the rates of success is in fact a verified tendency and the extent to which each of the possible explanations advanced here have contributed to this improvement (e.g., scientific progress in the fields of strategy implementation and change management, better management education programmes, time since adoption of a strategy and familiarity with it, accumulation of knowledge, particularly from the experience of early adopters, and customisation of general strategies). The identification of best practices, resulting from this line of research, might also play an important role in further promoting successful implementation.

Thirdly, whenever strategy implementation initiatives culminate in failure it is important 
to understand what the main causes for the failure were in order to identify if there are causes more important and frequent than others.

Finally, there seems to be, in some sectors of the literature reviewed, the view that some 'types' of strategic initiatives are easier to implement and succeed than others. While this view might be correct, it is important to bear in mind that it is not uncommon to find different studies comparing the success rates of the same types of strategic initiatives which derive considerably different estimates, suggesting that factors other than the type of strategy might play an important role in their success or failure.

Overall, while the real rate of strategy implementation failure might be difficult to determine with certainty, in-depth studies on these issues might shed some light on the matter, and help us understand why so many strategy implementation initiatives fail.

\section{Acknowledgement}

$==$ Included in title page $==$

\section{References}

A.T. Kearney (1992). Total Quality: Time to Take Off The Rose Tinted Spectacles. Kempston: IFS Publications.

Alchian, A.A. (1950). Uncertainty, evolution, and economic theory. Journal of Political Economy, 58(3), 211-221.

Aldrich, H.E. (1979). Organizations and Environments. New Jersey: Prentice-Hall.

Alexander, L.D. (1985). Successfully implementing strategic decisions. Long Range Planning, 18(3), 91-97.

Amitabh, M. (2010). Research in strategy-structure-performance construct: review of trends, paradigms and methodologies. Journal of Management and Organization, 16(5), 744763.

Ansoff, H.I. (1965). Corporate Strategy. New York: McGraw Hill. 
Ansoff, H.I., Declerck, R.P. and Hayes, R.L. (1976). From Strategic Planning to Strategic Management. New York: John Wiley \& Sons.

Ansoff, H.I. and McDonnell, E. (1990). Implanting Strategic Management. New York: Prentice Hall International.

Arthur D. Little (1992). Executive Caravan TQM Survey Summary, Arthur D. Little Corporation, Cambridge, MA.

Baden-Fuller, C. and Stopford, J.M. (1994). Rejuvenating the Mature Business: The Competitive Challenge. Boston, MA: Harvard Business School Press.

Balogun, J. and Hailey, V.H. (2008). Exploring Strategic Change. Harlow: Pearson.

Barnett, W.P. and Carroll, G.R. (1995). Modeling internal organizational change. Annual Review of Sociology, 21(1), 217-236.

Barney, J.B. (2001). Is the Resource-based 'View' a useful Perspective for Strategic Management Research? Yes. Academy of Management Review, 26(1), 41-56.

Bauer, J., Falshaw, R. and Oakland, J.S. (2005). Implementing Business Excellence. Total Quality Management, 16(4), 543-553.

Beamish, P.W. (1985). The characteristics of joint ventures in developed and developing countries. Columbia Journal of World Business, Fall, 20(2), 13-19.

Becer, E., Hage, B., McKenna, M. and Wilczynski, H. (2007). Performance-improvement initiatives - three best practices for project success, Booz Allen Hamilton. Available from www.boozallen.com, downloaded Nov. 2007.

Beer, M. and Eisenstat, R.A. (2000). The silent killers of strategy implementation and learning. Sloan Management Review, 41(4), 29-40.

Beer, M. and Nohria, N. (2000). Cracking the code of change. Harvard Business Review, 78(3), 133-141.

Bockmühl, S., König, A., Enders, A., Hungenberg, H. and Puck, J. (2011). Intensity, timeliness, and success of incumbent response to technological discontinuities: a synthesis and empirical investigation. Review of Managerial Science, 5(4), 265-289.

Burnes, B. (2004). Kurt Lewin and the planned approach to change: a re-appraisal. Journal of Management Studies, 41(6), 977-1002.

Burnes, B. (2005). Complexity theories and organizational change. International Journal of 
Management Reviews, 7(2), 73-90.

Calori, R., Baden-Fuller, C. and Hunt, B. (2000). Managing change at Novotel: back to the future. Long Range Planning, 33(6), 779-804.

Cândido, C.J.F. and Morris, D.S. (2000). Charting service quality gaps. Total Quality Management, 11(4-6), 463-472.

Cândido, C.J.F. and Morris, D.S. (2001). The implications of service quality gaps for strategy implementation. Total Quality Management, 12(7/8), 825-833.

Cândido, C.J.F. and Santos, S.P. (2011). Is TQM more difficult to implement than other transformational strategies? Total Quality Management, 22(11), 1139-1164.

Carnall, C.A. (1986). Managing strategic change: an integrated approach. Long Range Planning, 19(6), 105-115.

Chandler, A.D. (1962). Strategy and Structure: Chapters in the History of the American Industrial Enterprise. Cambridge: The MIT Press.

Charan, R. and Colvin, G. (1999). Why CEOs Fail. Fortune, 139(12), 68-78.

Cohen, M.D., March, J.G. and Olsen, J.P. (1972). A garbage can model of organisational choice. Administrative Science Quarterly, 17(1), 1-25.

Corboy, M. and Corrbui, D. (1999). The seven deadly sins of strategy implementation, Management Accounting. 77(10), 29-30.

Cyert, R.M. and March, J.G. (1964). The behavioral theory of the firm: a behavioral science economics amalgam. In: Cooper, W.W., Leavitt, H.J. and Shelly, M.W. (Ed.) New Perspectives in Organizational Research. New York: John Wiley \& Sons.

Dean, J.W. and Sharfman, M.P. (1993). Procedural rationality in the strategic decisionmaking process. Journal of Management Studies, 30(4), 587-610.

Dean, J.W. and Bowen, D.E. (1994). Management theory and total quality management: improving research and practice through theory development. Academy of Management Review, 19(3), 392-418.

DeGeus, A.P. (1988). Planning as learning. Harvard Business Review, 66(2), 70-74.

Dion, C., Allday, D., Lafforet, C., Derain, D. and Lahiri, G. (2007). Dangerous Liaisons, Mergers and Acquisitions: The Integration Game, Report by Hay Group, Philadelphia, USA, 1-16. Available from www.haygroup.com, accessed on May 2008. 
Dooyoung, S., Kalinowski, J.G. and El-Enein, G.A. (1998). Critical implementation issues in total quality management. Advanced Management Journal, Winter, 63(1), 10-14.

Dow, D., Samson, D. and Ford, S. (1999). Exploding the myth: do all quality management practices contribute to superior quality performance?. Production and Operations Management, Spring, 8(1), 1-27.

Doyle, M., Claydon, T. and Buchanan, D. (2000). Mixed results, lousy process: the management experience of organizational change. British Journal of Management, 11(3), S59-S80.

Dunphy, D.C. and Stace, D.A. (1988). Transformational and coercive strategies for planned organizational change: beyond the O. D. model. Organization Studies, 9(3), 317-334.

Dyason, M.D. and Kaye, M.M. (1997). Achieving real business advantage through the simultaneous development of managers and business excellence. Total Quality Management, 8(2/3), 145-151.

Economist Intelligence Unit (2013). Why Good Strategies Fail: Lessons from the C-Suite. London: Economist Intelligence Unit Limited.

Edmondson, A.C. (2011). Strategies for learning from failure. Harvard Business Review, 89(4), 48-55.

Eisenhardt, K.M. and Zbaracki, M.J. (1992). Strategic decision making. Strategic Management Journal, 13(8), 17-37.

Franken, A., Edwards, C. and Lambert, R. (2009). Executing strategic change: understanding the critical management elements that lead to success. California Management Review, $51(3), 49-73$.

Fredrickson, J.W. and Mitchell, T.R. (1984). Strategic decision processes: comprehensiveness and performance in an industry with an unstable environment. Academy of Management Journal, 27(2), 399-423.

Fredrickson, J.W. and Iaquinto, A.L. (1989). Inertia and creeping rationality in strategic decision processes. Academy of Management Journal, 32(3), 516-542.

French, S.N.J., Kouzmin, A. and Kelly, S.J. (2011). Questioning the epistemic virtue of strategy: The emperor has no clothes! Journal of Management and Organization, 17(4), 434-447. 
Galpin, T.J. (1997). Making Strategy Work - Building Sustainable Growth Capability. San Francisco: Jossey-Bass Publishers.

Gandolfi, F. and Hansson, M. (2010). Reduction-in-force (RIF) - New developments and a brief historical analysis of a business strategy. Journal of Management and Organization, 16(5), $727-743$.

Gandolfi, F. and Hansson, M. (2011). Causes and consequences of downsizing: Towards an integrative framework. Journal of Management and Organization, 17(4), 498-521.

Gioia, D.A. and Chittipeddi, K. (1991). Sensemaking and Sensegiving in Strategic Change Initiation. Strategic Management Journal, 12(6), 433-448.

Golembiewski, R.T. (1990). The irony of ironies: silence about success rates. In Golembiewski, R. T. (Ed.) Ironies in Organizational Development. New Jersey, USA: Transaction Publications.

Golembiewski, R.T., Proehl, C.W. and Sink, D. (1981). Success of OD applications in the public sector: toting up the score for a decade, more or less. Public Administration Review, 41(6), 679-682.

Golembiewski, R.T., Proehl, C.W. and Sink, D. (1982). Estimating the success of OD applications. Training and Development Journal, 36(4), 86-95.

Goss, D. (2008). Enterprise Ritual: A Theory of Entrepreneurial Emotion and Exchange. British Journal of Management, 19(2), 120-137.

Gray, D.H. (1986). Uses and misuses of strategic planning. Harvard Business Review, 64(1), 89-97.

Hackett Group (2004a). Balanced Scorecards: Are Their 15 Minutes of Fame Over?, The Hackett Group, Miami. Summary available from www.thehackettgroup.com, downloaded April 2008.

Hackett Group (2004b). Most Executives are Unable to Take Balanced Scorecards from Concept to Reality, Press Release, The Hackett Group, Miami, October, 1-4.

Hafsi, T. (2001). Fundamental dynamics in complex organizational change: a longitudinal inquiry into Hydro-Québec's management. Long Range Planning, 34(5), 557-583.

Hall, G., Rosenthal, J., Wade, J. (1993). How to make reengineering really work. Harvard Business Review, 71(6), 119-131. 
Hambrick, D.C. and Mason, P.A. (1984). Upper Echelons: The Organization as a Reflection of its Top Managers. Academy of Management Review, 9(2), 193-206

Hambrick, D.C. and Chen, M. (2008). New academic fields as admittance-seeking social movements: the case of strategic management. Academy of Management Review, 33(1), $32-54$.

Hannan, M.T. and Freeman, J. (1977). The population ecology of organizations. American Journal of Sociology, 82(5), 929-964.

Harrigan, K.R. (1988a). Strategic alliances and partner asymmetries. Management International Review, 28(4), 53-72.

Harrigan, K.R. (1988b). Joint ventures and competitive strategy. Strategic Management Journal, 9(2), 141-158.

Harrigan, K.R. (1988c). Joint ventures: a mechanism for creating strategic change. In Pettigrew, A. M. (Ed.) The Management of Strategic Change. New York: Basil Blackwell.

Hart, S.L. (1992). An integrative framework for strategy-making processes. Academy of Management Review, 17(2), 327-351.

Hickson, D.J., Miller, S.J. and Wilson, D.C. (2003). Planned or Prioritized? Two Options for Managing the Implementation of Strategic Decisions?. Journal of Management Studies, 40(7), 1803-1836.

Holder, T. and Walker, L. (1993). TQM Implementation. Journal of European Industrial Training, 17(7), 18-21.

Hrebiniak, L.G. (2006). Obstacles to effective strategy implementation. Organizational Dynamics, 35(1), 12-31.

Hughes, M. (2011). Do 70 per cent of all organizational change initiatives really fail? Journal of Change Management, 11(4), 451-464.

Hussey, D. (1996). A framework for implementation. In: Hussey, D. (Ed.) The Implementation Challenge. Chichester, England: John Wiley \& Sons.

Jørgensen, H.H., Owen, L. and Neus, A. (2008). Making Change Work. Somers: IBM.

Jantz, C.J. and Kendall, D.A. (1991). Consumer-driven innovative product development. Prism, 1, 24-29. Available from www.adlittle.com, downloaded Nov. 2007. 
Johnson, G. and Scholes, K. (1999). Exploring Corporate Strategy: Text and Cases. New York: Prentice Hall.

Judson, A.S. (1991). Invest in a high-yield strategic plan. The Journal of Business Strategy, July/August, 34-39.

Kaplan, R.S. and Norton, D.P. (2001). The Strategy-Focused Organization - How Balanced Scorecard Companies Thrive in the New Business Environment. Boston, MA: Harvard Business School Press.

Kiechel, W. (1982). Corporate strategists under fire. Fortune, December, 106(13), 34-39.

Kiechel, W. (1984). Sniping at strategic planning. Planning Review, May, 8-11.

Korukonda, A.R., Watson, J.G., and Rajkumar, T.M. (1999). Beyond teams and empowerment: a counterpoint to two common precepts in TQM. Advanced Management Journal, Winter, 29-36.

Kotter, J.P. (1995). Leading change: why transformation efforts fail. Harvard Business Review, 73(2), 59-67.

Krogh, G. and Vicari, S. (1993). An autopoiesis approach to experimental strategic learning. In Lorange, P., Chakravarthy, B., Roos, J. and Van de Ven, A. (Eds.) Implementing Strategic Processes, Change Learning \& Co-operation. Cambridge: Basil Blackwell.

Lawson, R., Stratton, W. and Hatch, T. (2006). Scorecarding goes global - companies around the world are deriving benefits from performance management tools. Strategic Finance, 87(9), 35-41.

Lawson, R., Hatch, T. and Desroches, D. (2008). Scorecard Best Practices: Design, Implementation, and Evaluation. New Jersey, USA: John Wiley \& Sons.

Learned, E.P., Christensen, C.R., Andrews, K.R. and Guth, W.D. (1965). Business Policy Text and Cases. Illinois: Irwin.

Lewin, K. (1947). Frontiers in group dynamics. In: Lewin, K. (1952) (Ed.) Field Theory in Social Science - Selected Theoretical Papers. London: Tavistock Publications.

Lewy, C.P. and Mée, A.F. (1998a). In de kaart laten kijken, de tien geboden bij BSCimplementaties, versie 1.0. Management Control and Accounting, 2, 32-37.

Lewy, C.P. and Mée, A.F. (1998b). Balanced Scorecard - Implementing the Ten Commandments. London: KPMG Consulting. 
Makino, S., Chan, C.M., Isobe, T. and Beamish, P.W. (2007). Intended and unintended termination of international joint ventures. Strategic Management Journal, 28(11), 11131132.

Mankins, M.C. and Steele, R. (2005). Turning great strategy into great performance, Harvard Business Review, 83(7/8), 65-72.

March, J.G. (1981). Footnotes to organizational change. Administrative Science Quarterly, 26(4), 563-577.

March, J.G. (1997). The technology of foolishness. In: Pugh, D.S. (Ed.) Organisation Theory - Selected Readings. London: Penguin Books.

Mellahi, K. and Wilkinson, A. (2004). Organizational failure: a critique of recent research and a proposed integrative framework. International Journal of Management Reviews, 5/6(1), $21-41$.

McCunn, P. (1998). The balanced scorecard: the eleventh commandment. Management Accounting, December, 34-36.

McKinsey (2006). Improving strategic planning: a McKinsey survey. The McKinsey Quarterly, 1-11. Available from www.mckinseyquarterly.com, downloaded Nov. 2007.

McKinsey (2008). Creating organizational transformations. The McKinsey Quarterly, 1-7. Available from www.mckinseyquarterly.com, downloaded Nov. 2011.

Miller, S. (1997). Implementing strategic decisions: four key factors. Organisation Studies, 18(4), 577-602.

Miller, S., Wilson, D. and Hickson, D. (2004). Beyond planning strategies for successfully implementing strategic decisions. Long Range Planning, 37(3), 201-218.

Mintzberg, H. (1987). Crafting strategy. Harvard Business Review, 65(4), 66-75.

Mintzberg, H. (1994). The Rise and Fall of Strategic Planning. New York: Prentice Hall.

Mintzberg, H. and Waters, J.A. (1985). Of strategies, deliberate and emergent. Strategic Management Journal, 6(3), 257-272.

Mintzberg, H., Raisinghani, D. and Théorêt, A. (1976). The structure of 'unstructured' decision processes. Administrative Science Quarterly, 21(2), 246-275.

Mintzberg, H., Ahlstrand, B. and Lampel, J. (1998). Strategy Safari-A Guided Tour Through the Wilds of Strategic Management. London: Prentice Hall. 
Mockler, R.J. (1995). Strategic management: the beginning of a new era. In: Hussey, D.E. (Ed.) Rethinking Strategic Management. Chichester: John Wiley \& Sons.

Mohrman, S.A., Tenkasi, R.V., Lawler III, E.E. and Ledford Jr., G.E. (1995). Total quality management: practice and outcomes in the largest US firms. Employee Relations, 17(3), 26-41.

Morisawa, T. and Kurosaki, H. (2003). Using the balanced scorecard in reforming corporate management systems. Nomura Research Institute Papers, December, 71, 1-15.

Naranjo-Gil, D., Hartmann, F. and Maas, V.S. (2008). Top Management Team Heterogeneity, Strategic Change and Operational Performance. British Journal of Management, 19(3), 222-234.

Neely, A. and Bourne, M. (2000). Why measurement initiatives fail. Measuring Business Excellence, 4(4), 3-6.

Nelson, R.R. and Winter, S.G. (1974). Neoclassical vs. evolutionary theories of economic growth: critique and prospectus. The Economic Journal, 84(336), 886-905.

Nonaka, I. (2007). The knowledge-creating company. Harvard Business Review, 85(7/8), $162-171$

Nutt, P.C. (1987). Identifying and appraising how managers install strategy. Strategic Management Journal, 8(1), 1-14.

Nutt, P.C. (1999). Surprising but true: half the decisions in organizations fail. Academy of Management Executive, 13(4), 75-90.

O’Brien, C. and Voss, C.A. (1992). In Search of Quality - An Assessment of 42 British Organizations using the Criteria of the Baldrige Award, Operations Management paper 92/02, London Business School.

O'Shannassy, T. (2001). Lessons from the evolution of the strategy paradigm. Journal of Management and Organization, 7(1), 25-37.

O'Shannassy, T. (2010). Board and CEO practice in modern strategy-making: How is strategy developed, who is the boss and in what circumstances? Journal of Management and Organization, 16(2), 280-298.

O'Toole, J. (1995). Leading Change: Overcoming the Ideology of Comfort and the Tyranny of Custom. San Francisco: Jossey-Bass. 
Papadakis, V. M., Lioukas, S. and Chambers, D. (1998). Strategic decision-making process: the role of management and context. Strategic Management Journal, 19(2), 115-147.

Park, S. (1991). Estimating success rates of quality circle programs: public and private experiences. Public Administration Quarterly, Spring, 15(1), 133-146.

Pautler, P.A. (2003). The Effects of Mergers and Post-Merger Integration: A Review of Business Consulting Literature, Draft paper, Federal Trade Commission, Bureau of Economics, 1-41. Available from www.ftc.gov/be/rt/businesreviewpaper.pdf, accessed on March 2008.

Pettigrew, A.M. (1987). Context and action in the transformation of the firm. Journal of Management Studies, 24(6), 649-670.

Pinto, J.K. and Prescott, J.E. (1990). Planning and tactical factors in the project implementation process. Journal of Management Studies, 27(3), 305-327.

Powell, T.C. (1995). Total quality management as competitive advantage: a review and empirical study. Strategic Management Journal, 16(1), 15-37.

Prajogo, D.I. and Brown, A. (2006). Approaches to adopting quality in SMEs and the impact on quality management practices and performance. Total Quality Management, 17(5), $555-566$.

Project Management Institute (2014). The High Cost of Low Performance. Newtown Square: Project Management Institute.

Prospectus Strategy Consultants (1996). Profiting from increased consumer sophistication - a survey of retail financial services in Ireland and Great Britain, Prospectus Strategy Consultants, Dublin, Ireland.

Quinn, J.B. (1989). Strategic change: 'logical incrementalism'. Sloan Management Review, Summer, 30(4), 45-60.

Raps, A. (2005). Strategy implementation - an insurmountable obstacle?. Handbook of Business Strategy, 141-146.

Rumelt, R.P., Schendel, D.E. and Teece, D.J. (1994). Fundamental issues in strategy. In Rumelt, R.P., Schendel, D.E. and Teece, D.J. (Ed.), Fundamental Issues in Strategy - A Research Agenda. Boston: Harvard Business School Press.

Senge, P. (1990). The leader's new work: building learning organizations. Sloan Management 
Review, Fall, 32(1), 7-23.

Sila, I. (2007). Examining the effects of contextual factors on TQM and performance through the lens of organisational theories: an empirical study. Journal of Operations Management, 25(1), 83-109.

Sirkin, H.L., Keenan, P. and Jackson, A. (2005). The hard side of change management. Harvard Business Review, 83(10), 109-118.

Sitkin, S.B., Sutcliffe, K.M. and Schroeder, R.G. (1994). Distinguishing control from learning in total quality management: a contingency perspective. Academy of Management Review, 19(3), 537-564.

Smith, M. (2005). The balanced scorecard. Financial Management, February, 27-28.

Smith, S., Tranfield, D., Foster, M. and Whittle, S. (1994). Strategies for managing the TQ agenda. International Journal of Operations \& Production Management, 14(1), 75-88.

Soltani, E., Lai, P. and Gharneh, N.S. (2005). Breaking through barriers to TQM effectiveness: lack of commitment of upper-level management. Total Quality Management, 16(8/9), 1009-1021.

Stace, D.A. and Dunphy, D.C. (1996). Translating business strategies into action: managing strategic change. In Hussey, D. (Ed.) The Implementation Challenge. Chichester: John Wiley \& Sons.

Stanislao, J. and Stanislao, B.C. (1983). Dealing with resistance to Change. Business Horizons, 26(4), 74-78.

Stadler, C. and Hinterhuber, H.H. (2005). Shell, Siemens and DaimlerChrysler: leading change in companies with strong values. Long Range Planning, 38, 467-484.

Sterling, J. (2003). Translating strategy into effective implementation: dispelling the myths and highlighting what works. Strategy \& Leadership, 31(3), 27-34.

Taylor, W.A. (1997). Leadership challenges for smaller organisations: self-perceptions of TQM implementation. Omega - The International Journal of Management Science, 25(5), 567-579.

Taylor, W.A. and Wright, G.H. (2003). A longitudinal study of TQM implementation: factors influencing success and failure. Omega - The International Journal of Management Science, 31(2), 97-111. 
The Economist (1992). The cracks in quality. The Economist, April 18, 69-70.

Van de Ven, A.H. and Poole, M.S. (1995). Explaining development and change in organizations. Academy of Management Review, 20(3), 510-540.

Voss, C.A. (1988). Success and failure in advanced manufacturing technology. International Journal of Technology Management, 3(3), 285-297.

Voss, C.A. (1992). Successful innovation and implementation of new processes. Business Strategy Review, Spring, 29-44.

Waclawski, J. (2002). Large-scale organizational change and performance: an empirical examination. Human Resource Development Quarterly, 13(3), 289-305.

Walsh, A., Hughes, H., Maddox, D.P. (2002). Total quality management continuous improvement: is the philosophy a reality?. Journal of European Industrial Training, 26(6), 299-307.

Weick, K.E. and Quinn, R.E. (1999). Organizational change and development. Annual Review of Psychology, 50(1), 361-386.

Wernham, R. (1985). Obstacles to strategy implementation in a nationalized industry. Journal of Management Studies, 22(6), 632-648.

Wilkinson, A. and Mellahi, K. (2005). Organizational failure. Long Range Planning, 38(3), 233-238.

Wilkinson, A., Redman, T. and Snape, E. (1994). The problems with quality management the view of managers: findings from an Institute of Management survey. Total Quality Management, 5(6), 397-406.

Woodley, P.M. (2006). Culture management through the balanced scorecard: a case study, unpublished PhD Thesis, Defence College of Management and Technology, Cranfield University.

Zairi, M. (1995). Strategic Planning Through Quality Policy Deployment: a Benchmarking Approach. In Kanji, G.K. (Ed.) Total Quality Management: Proceedings of the First World Congress. London: Chapman \& Hall. 


\section{Strategy implementation: What is the failure rate?}

Figure 1 - Business strategy implementation failure rates

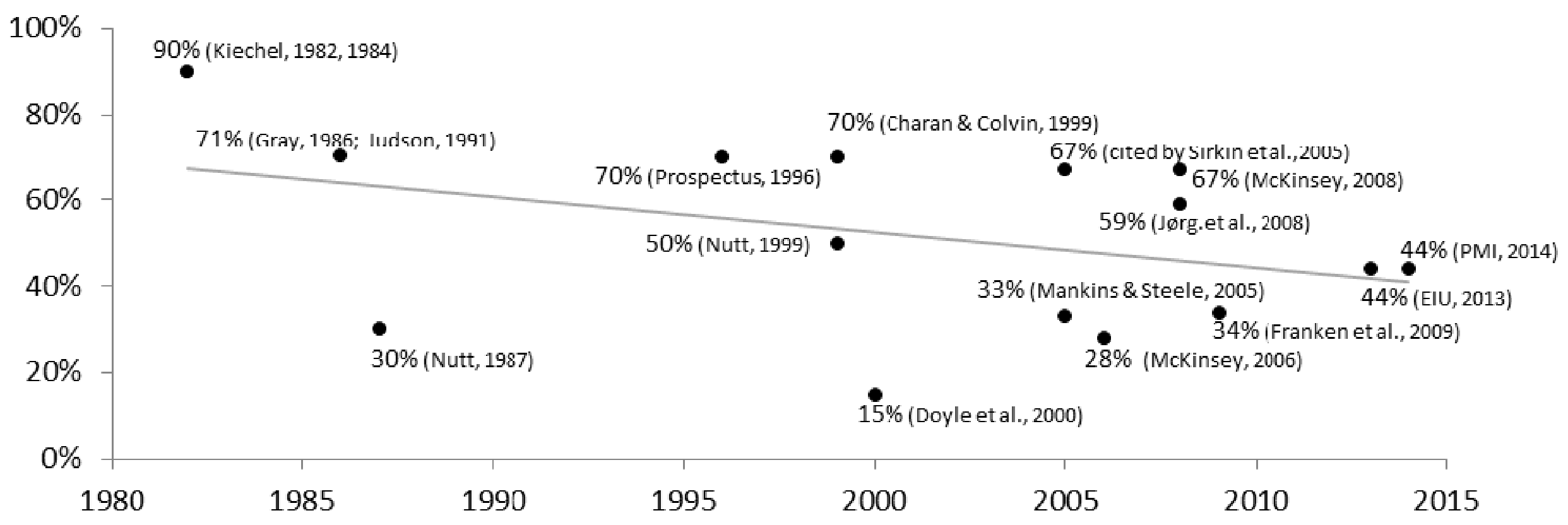

Note: For this figure, we used the rates in Table 1. When two rates were given in any one study, we used the average for the Figure. 


\begin{tabular}{|c|c|c|c|c|}
\hline Study & Method & Variable & $\begin{array}{l}\text { Rate of } \\
\text { failure }\end{array}$ & Obs. \\
\hline Kiechel $(1982,1984)$ & $\begin{array}{l}\text { Interviews carried out in the period of } 1979-1984 \text { with theoreticians, } \\
\text { corporate executives and consultants from most of the major consulting } \\
\text { firms. Complementary analysis of case studies and of the history of the } \\
\text { strategic management field. No research instrument explained and no } \\
\text { other information on methodology presented. }\end{array}$ & $\begin{array}{l}\text { Perception of the } \\
\text { percentage of companies } \\
\text { that can implement a } \\
\text { strategy successfully }\end{array}$ & $90 \%$ & $\begin{array}{l}\text { Kiechel }(1982,1984) \text { is cited by researchers such } \\
\text { as Mintzberg (1994) and Kaplan and Norton } \\
\text { (2001). We have searched the websites of some of } \\
\text { the companies interviewed by Kiechel (ADL, BCG, } \\
\text { McKinsey, Bain and others), looking for any studies } \\
\text { that the consultants interviewed might have been } \\
\text { quoting, and have also sent e-mails to these } \\
\text { companies asking for a copy. } \dagger\end{array}$ \\
\hline $\begin{array}{l}\text { Gray }(1986)^{*} \text { and } \\
\text { Judson }(1991)^{*} \text { (Gray- } \\
\text { Judson-Howard, Inc.) }\end{array}$ & $\begin{array}{l}\text { Questionnaire applied to chief executive officers, corporate planning } \\
\text { directors and business unit heads, all with substantial experience in } \\
\text { strategic planning in American multi-business corporations of the service } \\
\text { and manufacturing industries and in American Government Agencies. } \\
\text { Population and sampling method not clearly specified. Sample of } 300 \\
\text { respondents. Further details obtained through } 14 \text { Executive Seminars of a } \\
\text { day-and-a-half with the participation of } 216 \text { of those respondents. } \\
\text { Descriptive statistics only. }\end{array}$ & $\begin{array}{l}\text { Perceived failure of } \\
\text { strategic planning } \\
\text { systems, because of } \\
\text { difficulties in the } \\
\text { implementation phase }\end{array}$ & $51 \%-90 \%$ & $\begin{array}{l}\text { Based on Gray's (1986) results, we have } \\
\text { calculated the rate of failure: } 87 \% \text { x } 59 \%=51 \% \text {. } \\
\text { Judson (1991) quotes a rate of failure of around } \\
90 \% \text {, which was based on Gray's (1986) } 87 \% \\
\text { estimate. }\end{array}$ \\
\hline Nutt (1987) & $\begin{array}{l}\text { Case studies of } 68 \text { strategic planning projects in hospitals and other third } \\
\text { sector organisations from Canada and USA. Sample not random. Data } \\
\text { collected from interviews with key executives and company documents. } \\
\text { Additional interviews were made to secure an agreement between } \\
\text { interviewees' recall of events, existing documents and a written description } \\
\text { of the process prepared by the researcher. In case of lack of agreement } \\
\text { the case was not considered. Descriptives and statistical tests. }\end{array}$ & $\begin{array}{l}\text { Strategic projects } \\
\text { abandoned, rejected or } \\
\text { shelved. }\end{array}$ & $30 \%$ & $\begin{array}{l}\text { According to the author, the sample is not random } \\
\text { and a «positive bias may be present because } \\
\text { organisations that participate voluntarily are likely } \\
\text { to share information about practices and ideas they } \\
\text { believe to be high quality». This positive bias may } \\
\text { have resulted in an underestimated rate of failure. }\end{array}$ \\
\hline $\begin{array}{l}\text { Prospectus Strategy } \\
\text { Consultants (1996) * }\end{array}$ & n.a. & n.a. & $70 \%$ & $\begin{array}{l}\text { Quoted by Corboy and Corrbui * (1999). } \\
\text { Unfortunately, we could not find a copy. We } \\
\text { searched the Prospectus' web site and on several } \\
\text { national library on-line catalogues. We asked a } \\
\text { copy by e-mail sent to Prospectus and also to the } \\
\text { authors who quoted the study. } \dagger\end{array}$ \\
\hline $\begin{array}{l}\text { Charan and Colvin } \\
\text { (1999) }\end{array}$ & $\begin{array}{l}\text { 'Several dozen CEO failures' observed over decades by the authors as } \\
\text { management consultants (personal experience) and telephone call } \\
\text { interviews with CEOs chosen by Fortune. Selection method not specified. } \\
\text { Size of telephone calls sample: } 38 \text {. Some CEOs did not agree with views } \\
\text { expressed by the authors. Descriptive statistics only. }\end{array}$ & $\begin{array}{l}\text { Number of strategies } \\
\text { that, in the authors' view, } \\
\text { failed because of bad } \\
\text { implementation }\end{array}$ & $70 \%$ & $\begin{array}{l}\text { Charan and Colvin (1999) estimated that } 70 \% \text { of } \\
\text { the strategies that fail, do so, because of bad } \\
\text { implementation. Contrary to Kaplan and Norton's } \\
\text { (2001:1) generalization, they did not estimate that } \\
70 \% \text { of business strategies fail! }\end{array}$ \\
\hline Nutt (1999) & $\begin{array}{l}\text { Case studies of } 356 \text { decisions made by senior managers in medium to } \\
\text { large organisations of the public, private and third-sector in the USA and } \\
\text { Canada. Data collected from interviews with key participants and company } \\
\text { documents. Additional interviews were made to secure an agreement } \\
\text { between interviewees' recall of events, existing documents and a written } \\
\text { description of the decision process prepared by the researcher. In case of } \\
\text { lack of agreement the decision was not considered. }\end{array}$ & $\begin{array}{l}\text { Interviewers' perceptions } \\
\text { on how long a decision } \\
\text { holds valid and how } \\
\text { much of the decision } \\
\text { holds after two years }\end{array}$ & $50 \%$ & \\
\hline
\end{tabular}


Table 1 - Studies estimating general business strategy implementation failure rates (continuation)

\begin{tabular}{ll} 
Study & Method \\
\hline Doyle et al. (2000) & $\begin{array}{l}\text { Postal survey mailed in June } 1998 \text { to } 83 \text { members of the Organization } \\
\text { Development and Change Forum in the UK, Leicester, with a request to } \\
\text { ask up to four other management colleagues also to complete the } \\
\text { questionnaires. A total of } 415 \text { questionnaires were sent, and 92 replies } \\
\text { were received from managers of } 14 \text { public and } 14 \text { private-sector } \\
\text { organizations. These included } 24 \text { senior managers and } 68 \text { middle } \\
\text { managers with significant involvement and extensive experience in change } \\
\text { management / implementation. Descriptive statistics only. }\end{array}$ \\
$\begin{array}{l}\text { Mankins and Steele } \\
(2005)^{*} \text { (Marakon } \\
\text { Associates) }\end{array}$ & $\begin{array}{l}\text { Survey conducted by Marakon and the Economist Intelligence Unit in the } \\
\text { fall of 2004. Sample of senior executives from 197 companies worldwide } \\
\text { with sales exceeding USD 500 million. The sample includes very different } \\
\text { product markets and geographies. No other information on methodology } \\
\text { available. Descriptive statistics only. }\end{array}$
\end{tabular}

Unknown, cited by Sirkin et al. (2005) * (BCG)

McKinsey (2006) *

Jørgensen et al. (2008) * (IBM Global Business Services) and 1,000 employees $(64 \%)$, and less than 1,000 employees $(22 \%)$

McKinsey (2008) *
On-line survey. Sample size 796 from a worldwide panel of executives responsible for finance or strategy in organizations from a wide range of industries, each with a revenue of at least 500 million USD. No other

information available on sampling and methodology. Descriptives only.

Survey of 1532 practitioners - project leaders, sponsors, project managers and change managers - from companies of 15 different nations in the world and in 21 different industries. Sample included practitioners from companies with more than 100,000 employees (14\%), between 100,000 Practitioners were responsible for a wide range of projects with a diverse range of objectives. Additional data collected from in-depth interviews. The University of Bonn in Germany provided statistical support. No other

information on methodology available. Descriptive statistics only. and quality goals)

Survey of 3199 executives from industries and regions around the world. No other information on methodology available. Descriptive statistics only.
Variable

Perceived benefit / damage of long term strategic changes

implemented

Perceived degree of achievement of the financial objectives established

Perceived effectiveness of the strategic plan

Number of projects that did not miss any of the objectives (time, budget

Rate of

failure

Obs.

$8 \%-22 \%$ Two items were used to measure success / failure. For the first item, results indicate that $8 \%$ of the managers agree or strongly agree that changes have been widely damaging to the organization. For the second item, results show that $22 \%$ disagree or strongly disagree that the changes introduced have been broadly beneficial.

Failure defined for the purpose of building this table as achieving less than $50 \%$ of the potential financial performance of the strategic plan.

Sirkin et al. (2005) does not provide sufficient information to identify the original empirical study or studies. We asked all of the authors by e-mail to indicate the complete references for the studies. $\dagger$

According to the study, $59 \%$ of the projects «failed to fully meet their objectives: 44 percent missed at least one (time, budget or quality goals), while a full $15 \%$ either missed all goals or were stopped by management».

Perceived success of

organizational

transformations 
Table 1 - Studies estimating general business strategy implementation failure rates (continuation)

\begin{tabular}{|c|c|c|c|c|}
\hline Study & Method & Variable & $\begin{array}{l}\text { Rate of } \\
\text { failure }\end{array}$ & Obs. \\
\hline Franken et al. (2009) & $\begin{array}{l}\text { Questionnaire sent to organizations previously known to the researchers } \\
\text { and composed of } 50 \text { questions regarding the business internal and } \\
\text { external context, organization capability for successful implementation and } \\
\text { business performance. } 93 \text { completed questionnaires were returned from } \\
\text { predominantly large organizations in a variety of industry sectors. A pilot } \\
\text { was conducted with } 10 \text { organizations to ensure proper interpretation of the } \\
\text { questions. Subsequent focus group meetings were also conducted to } \\
\text { provide clarification and supporting insights. Descriptive statistics only. }\end{array}$ & $\begin{array}{l}\text { Perceived strategy } \\
\text { execution performance }\end{array}$ & $34 \%$ & $\begin{array}{l}\text { Thirty four percent of the organizations in the } \\
\text { sample reported strategy execution performance } \\
\text { below average. }\end{array}$ \\
\hline $\begin{array}{l}\text { Economist Intelligence } \\
\text { Unit (2013) }\end{array}$ & $\begin{array}{l}\text { Survey conducted by the Economist Intelligence Unit in March } 2013 . \\
\text { Sample of } 587 \text { senior executives from } 19 \text { different industries and from } \\
\text { North America }(30 \%) \text {, Asia Pacific ( } 30 \%) \text {, Western Europe }(21 \%) \text {, Middle } \\
\text { East, Africa, Latin America and Eastern Europe (19\%). Executives in the } \\
\text { sample are from companies with more than US\$10bn in annual revenue } \\
(25 \%) \text {, between US\$10bn and US\$1bn (33\%), or less than US } \$ 1 \mathrm{bn}(42 \%) \text {. } \\
\text { Additional data collected from } 7 \text { in-depth interviews with senior executives } \\
\text { and academics whose names are identified. No other information on } \\
\text { methodology available. Descriptive statistics only. }\end{array}$ & $\begin{array}{l}\text { Perceived success of } \\
\text { strategic initiatives in the } \\
\text { last three years }\end{array}$ & $44 \%$ & $\begin{array}{l}\text { The Economist Intelligence Unit provides } \\
\text { forecasting and analysis services based on } \\
\text { accurate and impartial assessments of the future in } \\
\text { order to deliver insights to decision-makers. The } \\
\text { Economist Intelligence Unit is not considered as a } \\
\text { consulting company. }\end{array}$ \\
\hline $\begin{array}{l}\text { Project Management } \\
\text { Institute (2014) }\end{array}$ & $\begin{array}{l}\text { Survey conducted by the Performance Management Institute and the } \\
\text { Economist Intelligence Unit in 2013-2014. Sample of over } 2500 \text { project } \\
\text { management leaders and practitioners from companies across North } \\
\text { America, Asia Pacific, Europe, Middle East, Africa, Latin America and the } \\
\text { Caribbean region. No other information on methodology available. } \\
\text { Descriptive statistics only. }\end{array}$ & $\begin{array}{l}\text { Perception of strategic } \\
\text { initiatives meeting their } \\
\text { original goals and } \\
\text { business intent }\end{array}$ & $44 \%$ & $\begin{array}{l}\text { Project Management Institute is a not-for-profit } \\
\text { professional membership association for the } \\
\text { project, program and portfolio management } \\
\text { profession. It is not considered as a consulting } \\
\text { company. }\end{array}$ \\
\hline
\end{tabular}

Notes: * Study by a consulting
n.a. Information not available.

† The study was not available on-line. We did not receive replies to our e-mails or the replies were negative. 
Table 2 - Studies estimating specific business strategy implementation failure rates

\section{Study}

Golembiewski et al.

$(1981,1982)^{*}$ and

Golembiewski (1990)

\section{Method}

Analysis of 574 case studies from the period 1945-1980, covering the

private $(53 \%)$ and the public sector $(47 \%)$, as well as USA $(83 \%)$ and non-

USA settings (17\%). Published and unpublished data sources were both

used. All cases were coded globally and for 308 individual variables.

Interrater reliabilities are high, 0,78 correlation and $95 \%$, respectively.

Differences in the global codification were reconciled after reliability check.

Beamish (1985)

Survey. Sample of 66 joint ventures in LDCs with at least 3 years of

existence; 20 joint ventures in Caribbean countries and 46 in other nonspecified LDCs; 12 involving a government partner, and 54 only private partners. Limited information on sampling and methodology. Descriptives only.

Harrigan (1988a, 1988b, Several sources of data used: archival data, field interviews, survey 1988c)

questionnaires, three-round delphi method questionnaire, telephone conversations, and follow-up letters. Sample size of 895 strategic alliances affecting commerce in the USA in 23 different industries (four-digit SIC codes) in de period 1924-1985, with parent companies from 19 countries. Limitations of the study derive from subjectivity of the delphi method and from differences in industries, joint-ventures and venture partners.

from differences in industries, joint-ventures and venture partners.
Descriptives and statistical tests associated with research questions.

Voss $(1988,1992)$

Study over a 18 month period of 14 companies implementing advanced manufacturing technologies. A case based approach was used, gathering data through interviews with executives and engineers in each firm. The data for each company was aggregated and examined to indicate whether there was an implementation success or failure. In the event of conflicting or inconclusive data, the case was excluded. Descriptives only. Given the sample size, rigorous conclusions were not reached.

Park (1991)

Analysis of 151 case studies from the period of 1978-1988. Published and unpublished sources of data. Internal documents of 45 organizations and interviews with 50 practitioners and researchers. All cases coded in term of 30 outcomes variables. Interrater reliability of $97 \%$, assessed for $20 \%$ of the cases. Descriptives and stratistical tests.

\section{Variable}

Probability of successfu

intervention based on

researchers' codification

Obs.

\% (global) Golembiewski (1990) and Golembiewski et al.

$-30 \%$

(multiple

variables

$(1981,1982)$ focus on the rate of success of

Organisational Development interventions. They

estimated two rates of success, one using a global assessment (86\% success) and another using the codification of 308 individual variables $(70 \%$ success).

Multinational enterprise managerial assessment of dissatisfaction with

performance

Mutual agreement

between perceptions of

both parent firms on the

success of the alliance

$61 \%$

Beamish (1985) is interested in joint ventures in DCs and LDCs.

$55 \% \quad$ Harrigan (1988a, 1988b) focused on strategic alliances.

competitiveness

improvement resulting

from the adoption of

new manufacturing

technology

(No. of positive outcomes

- no. of negative

outcomes) / total no. of

variables examined $\geq$

$50 \%$
Voss $(1988,1982)$ uses four measures of success: technical success, productivity increase, other benefits realized, such as quality improvement, and competitiveness improvement. Rates of success calculated are: $100 \%, 86 \%, 57 \%$ and $14 \%$, respectively. In the previous column of this table, the failure rate indicated is $100-14=86 \%$.

40\% Park (1991) focused on quality circles

programmes. We calculated the failure rate using the data provided in the paper as the average fo the public and the private organizations. 
Table 2 - Studies estimating specific business strategy implementation failure rates (continuation)

Study
$\begin{aligned} & \text { Method } \\ & \text { Unknown, cited by Jantz } \\ & \text { and Kendall (1991) * } \\ & \text { (Arthur D. Little) }\end{aligned}$
A. T. Kearney (1992) * Survey. Sample of over 100 British firms (according to The Economist,
1992).

\section{Variable}

n.a.

n.a.

Rate of

failure

Obs.

(1)

$90 \%$

The rate of failure refers to the proportion of new
consumer products that fail. Jantz and Kendall

(1991) do not provide sufficient information to

identify the original empirical study. We were

unable to establish contact with Jantz or Kendall. $†$

$80 \%$ †† This study has been abundantly cited, e.g., The Economist (1992), Wilkinson et al. (1994), and Soltani et al. (2005). Unfortunately, we could not Soltani et al. (2005). Unfortunately, we could not
find a copy. We searched A. T. Kearney's web site, several national library on-line catalogues (England, USA, Ireland, Scotland, Canada, Australia, Portugal), and Emerald web site (editor of the TQM Magazine). We asked a copy by e-mail sent to A.T. Kearney, to Emerald and also to the authors who quoted the study. $\dagger$

Hall et al. (1993) *

(McKinsey)

Wilkinson et al. (1994)

Lewy and Mée (1998a, 1998b) * (KPMG)

Walsh et al. (2002)
Case study. Sample of more than a hundred companies in different industries and locations. Detailed analysis of twenty cases. Limited information on sampling and methodology. Descriptives only.

Postal questionnaire sent to managers from all management levels and functions of public and private sector organizations of the UK and foreign owned companies. Several industries covered. Sample of 880 managers. Descriptive statistics only.

Case study. Analysis and comparison of the implementation and results obtained across seven European companies. No information on population or sampling method. No other information on methodology. Descriptives only.

Postal questionnaires sent to the senior managers of 170 selected medium and large-sized companies in Ireland. Selection method not specified. First questionnaire: sample size $n=72,51$ with a TQM programme. Second questionnaire: sample size $n=72,51$ with a TQM programme. Second questionnaire: sample size $n=28$, all of which $T Q M$ firms. Follow
clarify responses and secondary data. Descriptive statistics only.
Reduction in total business-unit costs

Improvement in earnings

(bering

Perceived overall

success of QM

programme

How many and how

firmly, in researchers

opinion, were the 'ten

commandments' adopted

by the company

Perceived overall success of TQM programme

$55 \%-70 \%$ Hall et al. (1993) estimated the percentage of Business Process Reengineering initiatives that failed.

29\% - 43\% Lewy and Mée (1998a) focused on the initiatives to implement a Balanced Scorecard. With the original study written in Dutch, we decided to use a translation with some editing, published by KPMG Consulting (Lewy and Mée, 1998b), and other additional sources that quote the study (McCunn, 1998; Smith, 2005; and Woodley, 2006). 
Table 2 - Studies estimating specific business strategy implementation failure rates (continuation)

\begin{tabular}{lll} 
Study & Method & Variable \\
\hline $\begin{array}{l}\text { Morisawa and Kurosaki } \\
(2003)^{*} \text { (Nomura } \\
\text { Research Institute Ltd.) }\end{array}$ & $\begin{array}{l}\text { Survey. Questionnaire conducted by the N.R.I. Ltd. in June 2003 among } \\
1330 \text { companies with sales of } 50 \text { billion Yen or more. No information on } \\
\text { sampling method. Sample size } n=189,35 \text { of which with a balanced } \\
\text { scorecard (18,5\%). Other methodological information not provided. } \\
\text { Descriptives only. }\end{array}$ & $\begin{array}{l}\text { Perceptual evaluation of } \\
\text { the results of introducing } \\
\text { the balanced scorecard }\end{array}$ \\
Pautler (2003) & $\begin{array}{l}\text { Comparative critical analysis of 13 studies made by consulting companies } \\
\text { on the success rate and factors contributing to effective mergers and post- } \\
\text { merger integration. Critical review of the consulting companies' studies and } \\
\text { comparison with academic research. Descriptives only. }\end{array}$ & $\begin{array}{l}\text { Raise in shareholder } \\
\text { value relative to pre-deal }\end{array}$ \\
\hline
\end{tabular}

comparison with academic research. Descriptives only.

Taylor and Wright (2003) Longitudinal study over a period of 5 years of a cohort of 109 TQM firms in Northern Ireland. Postal questionnaire mailed to CEOs or Managing Directors. Further details obtained through 25 follow up interviews. Stratified sample representative in terms of sector and size of firm. Descriptives and statistical tests associated with research hypotheses. Hackett Group (2004a, $\quad \begin{aligned} & \text { Survey of more than } 2400 \text { client organisations from several countries, } \\ & \text { including } 93 \text { percent of the Dow Jones Industrials, } 80 \text { percent of the }\end{aligned}$
2004b) ${ }^{*}$ $2004 b)^{*}$ Fortune 100 , and 90 percent of the Dow Jones Global Titans Index. No other information on methodology available. The full text of the study is available only to clients of the Hackett Group.

Lawson et al. (2006 2008) * (sponsored by professional and International on-line survey conducted in 44 countries and in eight different languages. Methods used to solicit survey participation were different across countries, but everyone could participate. Sample size of 382

consulting organisations) companies, divisions and subsidiaries Of these 382,193 (51\%) used a companies, divisions and subsidiaries. Of these 382, 193 (51\%) used a balanced scorecard. No non-response bias analysis available. Descriptives Perceived TQM outcome/success

Perceived maturity degree reached by the initiative

Perceived benefits to the organisation
Rate of

Obs.

$34 \%$

Morisawa and Kurosaki (2003) focused on the implementation of the balanced scorecard.
$45 \%-70 \%$

\section{Focuses on mergers and acquisitions. Concludes} that in spite of the weaknesses of the studies by consulting companies, the «broad pattern of results reported ... does not differ much from that found in
the finance/business academic field». In fact, the finance/business academic field». In fact,
«[f]ailure rates for mergers in the range of $35 \%$ to «[f]ailure rates for mergers in the range of $35 \%$ to
$60 \%$ are common in academic studies» Pautler (2003).

$41 \% \quad$ The rate of failure corresponds to the proportion of unsuccessful and of discontinued TQM programs

The Hackett Group focused on the development of a mature balanced scorecard. 'Mature' meaning that it does not have too many metrics, does not focus heavily on historical finance data and has enough forward-looking indicators.

$37 \%$ Lawson et al. $(2006,2008)$ focused on the implementation of the balanced scorecard. 
Table 2 - Studies estimating specific business strategy implementation failure rates (continuation)

\begin{tabular}{|c|c|c|c|c|}
\hline Study & Method & Variable & $\begin{array}{l}\text { Rate of } \\
\text { failure }\end{array}$ & Obs. \\
\hline $\begin{array}{l}\text { Dion et al. (2007) * (Hay } \\
\text { Group and La Sorbonne) }\end{array}$ & $\begin{array}{l}\text { Three phase study, including (1) interviews with } 200 \text { senior European } \\
\text { business leaders who were involved in a major merger or acquisition } \\
\text { during the previous } 3 \text { years; (2) 'desk research' into the } 100 \text { largest } \\
\text { mergers and acquisitions; and (3) qualitative and quantitative research } \\
\text { amongst } 300 \text { global employees of merging organisations. Descriptive } \\
\text { statistics only. No other information on methodology. }\end{array}$ & $\begin{array}{l}\text { Perceived degree to } \\
\text { which the initial } \\
\text { objectives of the initiative } \\
\text { were achieved }\end{array}$ & $91 \%$ & \\
\hline Makino et al. (2007) & $\begin{array}{l}\text { Data from an annual survey on overseas business activities conducted by } \\
\text { a Japanese Ministry. Database includes } 2000 \text { International Joint Ventures } \\
\text { (IJVs) that were terminated in the period of } 1996-2001 \text {, and all those that } \\
\text { were not terminated in the same period (total n.a.). Descriptives and } \\
\text { statistical tests associated with research hypotheses. }\end{array}$ & $\begin{array}{l}\text { Number of terminated } \\
\text { IJVs over the number of } \\
\text { IJVs that existed in the } \\
\text { same period }\end{array}$ & $\begin{array}{l}8 \% \text { (LDCs) } \\
11 \%(\mathrm{DCs})\end{array}$ & $\begin{array}{l}\text { Makino et al. (2007) focused on the intended and } \\
\text { unintended termination of international joint } \\
\text { ventures. }\end{array}$ \\
\hline Sila (2007) & $\begin{array}{l}\text { Mail survey sent to a selected key informant of each of the } 2000 \\
\text { manufacturing and service companies randomly selected from the ASQ } \\
\text { mailing list. Sample size: } 286 \text {. Responses tested for non response bias } \\
\text { and for scale reliability and validity. Descriptives and statistical tests } \\
\text { associated with research hypotheses. }\end{array}$ & $\begin{array}{l}\text { Perceived success of the } \\
\text { TQM program }\end{array}$ & $14 \%$ & \\
\hline $\begin{array}{l}\text { Unknown, cited by Becer } \\
\text { et al. (2007) }{ }^{*} \text { (Booz- } \\
\text { Allen-Hamilton) }\end{array}$ & n.a. & $\begin{array}{l}\text { Initiatives terminated or } \\
\text { producing less than } \\
\text { expected results }\end{array}$ & $40 \%$ & $\begin{array}{l}\text { Becer et al. (2007) focused on performance- } \\
\text { improvement initiatives. The authors do not provide } \\
\text { sufficient information to identify the original } \\
\text { empirical study or studies. We contacted all of } \\
\text { them by e-mail. } \dagger\end{array}$ \\
\hline
\end{tabular}

Notes: * Study by a consulting firm or by authors associated with consulting companies. † The study was not available on-line. We did not receive replies to our e-mails or the replies were negative. †† In the same year, in a study by O'Brien and Voss (1992), the authors concluded that most British organisations were having problems developing TQM. However, they noted that most UK organisations were in the early stages of developing a total approach to quality, i.e., in the beginning of implementation. LDCs less developed countries DCs developed countries n.a. Information not available. 